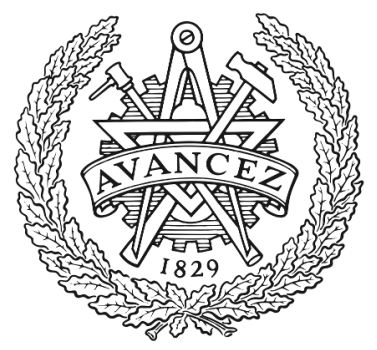

CHALMERS

UNIVERSITY OF TECHNOLOGY

\title{
Hydrological modelling in a drinking water catchment area as a means of evaluating pathogen risk reduction
}

Downloaded from: https://research.chalmers.se, 2023-04-26 04:08 UTC

Citation for the original published paper (version of record):

Bergion, V., Sokolova, E., Åström, J. et al (2017). Hydrological modelling in a drinking water catchment area as a means of evaluating pathogen risk reduction. Journal of Hydrology, 544: 74-85. http://dx.doi.org/10.1016/j.jhydrol.2016.11.011

N.B. When citing this work, cite the original published paper. 
Accepted version - Final version available: http://dx.doi.org/10.1016/j.jhydrol.2016.11.011

0022-1694/@2016 This version is made available under the CC-BY-NC-ND 4.0 license

\section{Hydrological modelling in a drinking water catchment area as a means of evaluating pathogen risk reduction}

Bergion, Viktor ${ }^{a *}$; Sokolova, Ekaterina ${ }^{\mathrm{a}}$; Åström, Johan ${ }^{\mathrm{b}}$; Lindhe, Andreas ${ }^{\mathrm{a}}$; Sörén, Kaisa ${ }^{\mathrm{c}}$, Rosén, Lars ${ }^{\mathrm{a}}$

a) Chalmers University of Technology, Department of Civil and Environmental Engineering, SE-412 96 Gothenburg, Sweden

b) Tyréns AB, Lilla Torget 3, SE-441 30 Alingsås, Sweden

c) National Veterinary Institute, SE-751 89 Uppsala, Sweden

* Corresponding author: viktor.bergion@chalmers.se,

0022-1694/C2016 This version is made available under the CC-BY-NC-ND 4.0 license

Final version available: http://dx.doi.org/10.1016/j.jhydrol.2016.11.011

Abstract:

Waterborne outbreaks of gastrointestinal diseases are of great concern to drinking water producers and can give rise to substantial costs to the society. The World Health Organisation promotes an approach where the emphasis is on mitigating risks close to the contamination source. In order to handle microbial risks efficiently, there is a need for systematic risk management. In this paper we present a framework for microbial risk management of drinking water systems. The framework incorporates cost-benefit analysis as a decision support method. The hydrological Soil and Water Assessment Tool (SWAT) model, which was set up for the Stäket catchment area in Sweden, was used to simulate the effects of four different mitigation measures on microbial concentrations. The modelling results showed that the two mitigation measures that resulted in a significant $(p<0.05)$ reduction of Cryptosporidium spp. oocyst and Escherichia coli concentrations were a vegetative filter strip linked to cropland and improved treatment (by one Log10 unit) at the wastewater treatment plants. The mitigation measure with a vegetative filter strip linked to grazing areas did not achieve any significant reduction in E.coli ( $p>0.05)$ but for Cryptosporidium spp. $(\mathrm{p}<0.05)$. The mitigation measure enhancing the removal efficiency of all on-site wastewater treatment systems (total removal of $2 \log 10$ units), did not achieve any significant reduction in E.coli or Cryptosporidium spp. concentrations ( $p>0.05$ ). The SWAT model was useful when characterising the effect of different mitigation measures on microbial concentrations. Hydrological modelling implemented within an appropriate risk management framework is a key decision support element as it identifies the most efficient alternative for microbial risk reduction.

Key words: Soil and Water Assessment Tool (SWAT); Cryptosporidium; E. coli; faecal contamination; risk management; decision support

Abbreviations $^{1}$

\footnotetext{
${ }^{1}$ CBA - Cost-benefit analysis

DWTP - Drinking water treatment plant

OWTS - On-site wastewater treatment system

SWAT - Soil and water assessment tool

WWTP - Wastewater treatment plant
} 
Accepted version - Final version available: http://dx.doi.org/10.1016/j.jhydrol.2016.11.011

0022-1694/@2016 This version is made available under the CC-BY-NC-ND 4.0 license

\section{Introduction}

\subsection{Background}

The World Health Organisation (WHO) states that microbial risks are of particular concern in the context of drinking water (WHO, 2011). Each case of illness results in a cost to society (including health care, production loss, discomfort from being ill etc.). In 2010 for example, the town of Östersund in Sweden experienced a waterborne outbreak of cryptosporidiosis and 27,000 people, almost half (45\%) of the town's population, fell ill. It was estimated that the event resulted in a cost to the society of approximately SEK 220 million (€23.5 million) (Lindberg et al., 2011).

Lake Mälaren in central Sweden is a drinking water source for two million people in the Stockholm area, and currently there is no sustainable alternative drinking water source. Cryptosporidium spp. oocysts have been detected in Lake Mälaren at the intakes of the three largest drinking water treatment plants (DWTPs) - Norsborg, Lovö and Görväln - that supply drinking water to the Stockholm area (Hansen, 2011). The spread of waterborne diseases through one of these DWTPs is considered to be the largest risk associated with water sources in the county of Stockholm (The Council of Water and Wastewater Cooperation in Stockholm County, 2011).

In order to prevent and reduce waterborne outbreaks, the WHO (2011) promotes a risk-based approach with an emphasis on mitigating the risks close to the contamination source. In this way, drinking water producers avoid relying solely on expensive technology in the DWTPs for water treatment. Faecal sources in a catchment area, and the associated risk of the presence of pathogens (e.g. E. coli O157:H7 and Cryptosporidium), could be of human or animal origin. These sources include wastewater (municipal wastewater treatment plants (WWTP) and sewage network systems as well as on-site wastewater treatment systems (OWTS)), grazing activities (both wild and domestic animals) and using manure as fertiliser. The presence of faecal sources is merely an indicator that pathogens might be present.

Microbial risks to surface waters can be mitigated by a variety of different measures (e.g. Åström and Pettersson, 2010; NZMH, 2014). In order to find the most appropriate mitigation measure, and wellfounded, structured risk-based decision support is needed. Risk-based decision models in combination with microbial monitoring and catchment area models can be very informative in this context (Oliver et al., 2016).

\subsection{Risk management framework}

Successful risk management requires the implementation and continuous use of a structured framework by the responsible organisation (ISO, 2009). Several frameworks for risk management in drinking water systems have been established (e.g. Lindhe, 2010; Lindhe et al., 2009; Rizak et al., 2003; Rosén et al., 2007; WHO, 2011; Yang et al., 2015). A general decision-making process when using cost-benefit analysis (CBA) as a decision support model was described by Aven (2012). A framework for a CBA of new technologies in drinking water supply systems has also been developed (Baffoe-Bonnie et al., 2008). In this paper, the aim is not to fully apply the presented simplified framework (Figure 1), but to place hydrological modelling in the context of facilitating risk estimations. The use of hydrological modelling to 
Accepted version - Final version available: http://dx.doi.org/10.1016/j.jhydrol.2016.11.011

0022-1694/@2016 This version is made available under the CC-BY-NC-ND 4.0 license

quantify health risks to drinking water consumers as well as the importance of monetising the health benefits of mitigation measures are highlighted.

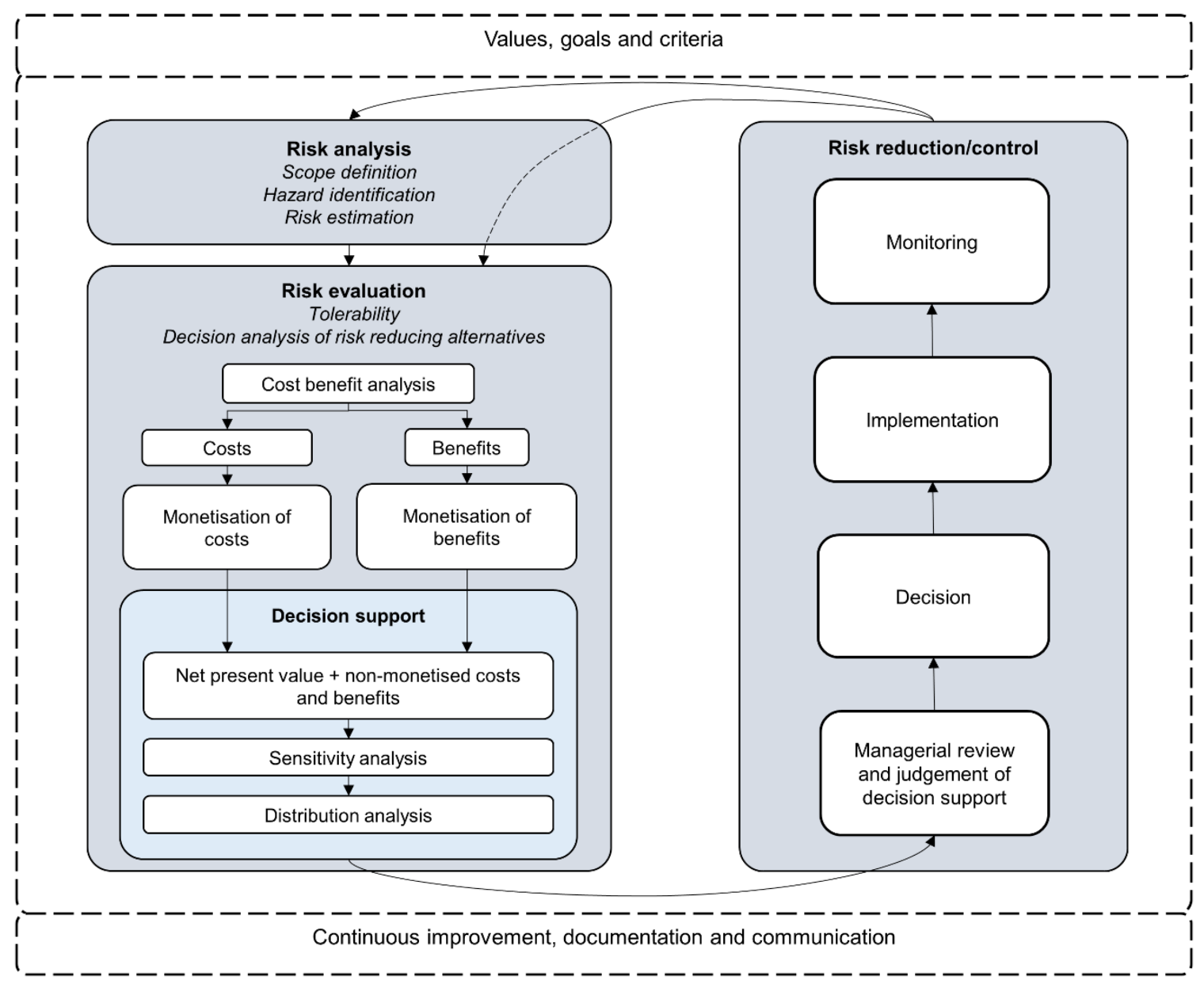

Figure 1 Framework for risk-based decision support with cost-benefit analysis as decision model.

Since the terminology used in risk-related frameworks may differ between different applications, the suggested framework is explained below. The main compartments in the framework are risk analysis, risk evaluation and risk reduction/control (Figure 1). In the first compartment, risk analysis, the scope is defined, hazards are identified and the final risk is estimated in a suitable manner. The aim and scope, also referred to as establishing the context (ISO, 2009), are to define system boundaries, internal and external parameters and components/activities within the system, and to establish risk criteria. Hazard identification provides a comprehensive description of the hazardous agents, events etc. that constitute problems in a specific case. This information forms the basis for estimating the final risk level and continued risk management. Risk estimation includes consideration of uncertainties, likelihoods and consequences associated with each identified hazard. Risk estimation can be supported by fate and transport modelling of contamination, since this type of modelling can provide input for quantitative microbial risk analysis (QMRA). The QMRA helps characterise each mitigation measure by providing an 
Accepted version - Final version available: http://dx.doi.org/10.1016/j.jhydrol.2016.11.011

0022-1694/@2016 This version is made available under the CC-BY-NC-ND 4.0 license

estimate of the health effects in terms, for example, of probability of infection or Disability Adjusted Life Years (DALY). Monetisation of the quantified health effects forms the basis for the health benefits included in the CBA, performed in the risk evaluation.

The risk evaluation compartment establishes tolerability and acceptability criteria in order to determine whether the risks described in the risk analysis need to be mitigated. If mitigation is needed, the decision analysis of risk-reducing alternatives will first identify available mitigation measures and then characterise the alternatives in terms of risk reduction and associated costs and benefits. This characterisation will render decision support in the form of a CBA including both the monetised and nonmonetised costs and benefits of each alternative. Sensitivity and distribution analyses aim to evaluate uncertainties in input data and results, and identify how costs and benefits are distributed in society. These analyses are part of the CBA and are vital if the decision-maker is to arrive at an informed, transparent and well-founded decision.

The last compartment is risk reduction/control, which includes a managerial review and assessment of decision support, decision, implementation and monitoring. Through managerial review and assessment of decision support, all parts of the decision support process are placed under scrutiny by the management or the decision-maker before the decision is made. After implementation of the decision, monitoring will ensure that any change that might lead to the need for a new decision is acknowledged.

This framework is a point of departure for comparing alternative ways of reducing health risks in a drinking water system using CBA as a decision support model. The preconditions for a dynamic and transparent framework are the values, goals and criteria set by various stakeholders, as well as continued improvement, documentation and communication. The basis for the framework consists of meticulous investigations and detailed analyses of raw water quality, catchment dynamics, investment costs, and benefits.

\subsection{Fate and transport modelling}

The fate and transport of faecal contamination and pathogens in the catchment area of a drinking water source can be analysed using hydrological models. Hydrological models can thus aid risk analysis as part of drinking water management by predicting high-risk events with regard to runoff and possible high pathogen concentrations in the water source (Coffey et al., 2010a). Furthermore, hydrological models can be useful when comparing alternative means of managing microbial risks in relation to water quality (Coffey et al., 2010c).

The Soil and Water Assessment Tool (SWAT) is a hydrological, process-based model for predicting the impact of land management practices on water quality (Nietsch et al., 2011). The SWAT model has been reported to be suitable for simulating the spread of contamination from non-point sources (Åström, 2013; Booty and Benoy, 2009; Coffey and Cummins, 2008) and to evaluate microbial risk (Coffey and Cummins, 2008). The SWAT model has also been used to simulate the fate and transport of faecal coliforms (e.g. Cho et al., 2012; Parajuli et al., 2009), Escherichia coli (e.g. Bougeard et al., 2011b; Coffey et al., 2010a; Kim et al., 2010) and Cryptosporidium (e.g. Coffey et al., 2010b; Jayakody et al., 2014; Tang et al., 2011). 
Accepted version - Final version available: http://dx.doi.org/10.1016/j.jhydrol.2016.11.011

0022-1694/@2016 This version is made available under the CC-BY-NC-ND 4.0 license

Cryptosporidium spp. is a parasite within the Cryptosporiidae family (Sunnotel et al., 2006) that infects humans, causing cryptosporidiosis, a diarrhoeal disease with symptoms such as stomach cramps, fever, vomiting, nausea, dehydration and weight loss (Centers for Disease Control and Prevention, 2014b). C. hominis and $C$. parvum are the species most associated with human infections (Centers for Disease Control and Prevention, 2014a), although other species, such as C. canis, C. felis, C. meleagridis and C. muris, have also been reported as being responsible for human infections (Sunnotel et al., 2006).

Modelling Cryptosporidium spp. oocyst fate and transport can be a useful complement to traditional faecal indicator monitoring and can provide information regarding the contribution of different faecal sources (Ferguson et al., 2007b). However, sufficient information on the faecal sources is essential for successful modelling.

\subsection{Objectives}

The objectives of this study were to:

- set up, validate and calibrate a hydrological (SWAT) model for the Stäket catchment area of Lake Mälaren in Sweden;

- investigate the applicability of the SWAT model in order to characterise mitigation measures for microbial risk reduction;

- describe the role of hydrological modelling as part of decision support in the context of microbial risk reduction using the proposed risk management framework (Figure 1)

\section{Methods}

Initial steps in the framework (Figure 1) identified a number of hazards, such as faecal sources of human and domestic animal origin. Wildlife were not included in the study since their pathogen contribution is generally smaller than for domestic animals (Ferguson et al., 2009), and that the focus of the mitigation measures was on anthropogenic activities. Hazards in the form of faecal sources, pose a microbial risk to drinking water consumers in the Stockholm region. The hydrological SWAT model was used to simulate the fate and transport of contamination originating from these faecal sources and to estimate the effects of risk mitigation measures. The effect of each measure, calculated in terms of Log10 reduction of $E$. coli and Cryptosporidium concentrations, was compared between the mitigation measures.

\subsection{Model area and setup}

The SWAT model (ArcSWAT version 2012.10_1.13) was set up for the period 2002-2011 for the Stäket catchment area, which is part of the drainage basin of Lake Mälaren (Figure 2). Faecal contamination sources in the area included WWTPs, OWTSs, manure application on agricultural land and manure from grazing suckler herds, dairy herds, sheep, and horses. 
a)<smiles>CC1CC(=O)C(=N)C1=N</smiles>

\begin{tabular}{|ll|}
\hline$\Delta$ Outflow \\
\hline$\quad$ Catchment area \\
\hline Stream \\
$\square$ Forestewater treatment plant \\
Grazing areas \\
Urban areas \\
$\square$ Water \\
$\square$ Agricultural land
\end{tabular}

$0 \quad 5 \quad 10 \quad 20 \mathrm{Km}$

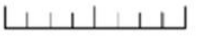

b)
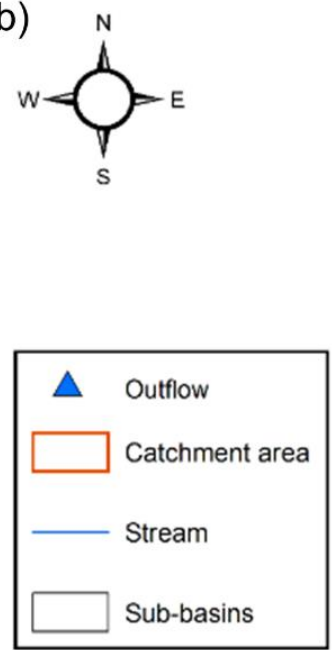

$0 \quad 5 \quad 10 \quad 20 \mathrm{Km}$

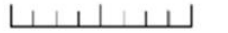

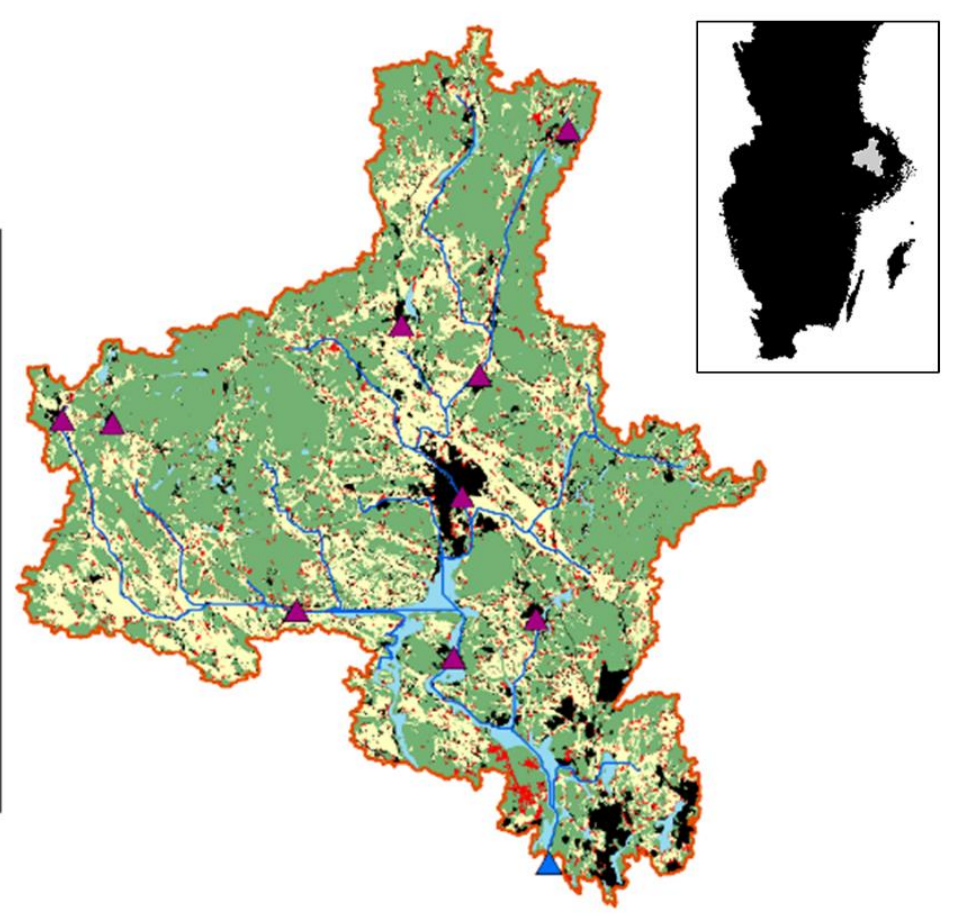

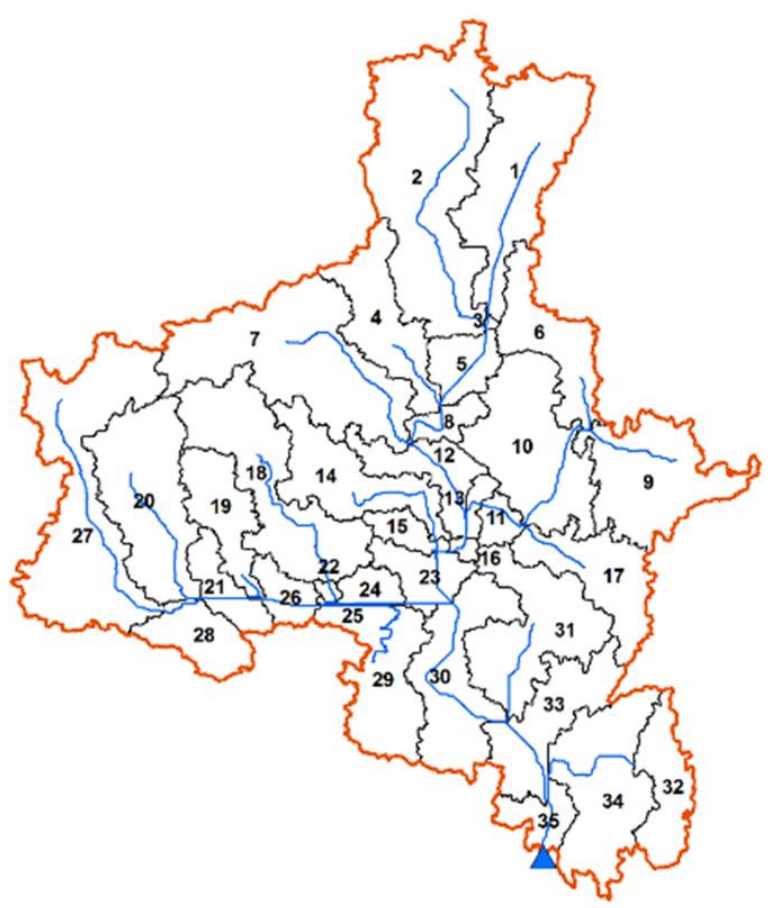

Figure 2 Maps of the Stäket catchment representing (a) land use and wastewater treatment plants (the location of the catchment in Sweden is marked in the right box) and (b) sub-basins defined by the SWAT model. 
Accepted version - Final version available: http://dx.doi.org/10.1016/j.jhydrol.2016.11.011

0022-1694/C2016 This version is made available under the CC-BY-NC-ND 4.0 license

The input data included topographical, geographical and geological Geographic Information Systems (GIS) information as well as meteorological data (Table 1). The total catchment area $\left(3,744 \mathrm{~km}^{2}\right)$ was divided into 35 sub-basins, ranging from 1 to $346 \mathrm{~km}^{2}$ in size (Figure 2). Calibration and validation of the model using water flow was performed for the periods 2003-2007 and 2008-2011 respectively. 2002 was used as a warm-up period. Detailed information regarding SWAT and its parameters can be found in Winchell et al. (2013).

Table 1 Input data for the hydrological model.

\begin{tabular}{llll}
\hline Data & Origin & File type & Resolution \\
\hline $\begin{array}{l}\text { Digital Elevation } \\
\text { Model }\end{array}$ & National Land Survey of Sweden & Raster & $50 \times 50 \mathrm{~m}$ \\
$\begin{array}{l}\text { Point source } \\
\text { location }\end{array}$ & PLC5 $^{\text {a }}$ & Text & Nine WWTP \\
$\begin{array}{l}\text { Land use } \\
\text { Soil }\end{array}$ & National Land Survey of Sweden & Shape & $25 \times 25 \mathrm{~m}$ \\
$\begin{array}{l}\text { Meteorological } \\
\text { data }\end{array}$ & $\begin{array}{l}\text { Swedish Meteorological and } \\
\text { Hydrological Institute }\end{array}$ & Shape & $\begin{array}{l}1: 25000-1: 100000, \\
\text { eight soil types }\end{array}$ \\
$\begin{array}{l}\text { Flow gauges } \\
\text { location }\end{array}$ & $\begin{array}{l}\text { Swedish Meteorological and } \\
\text { Hydrological Institute }\end{array}$ & Text & Daily recordings ${ }^{c}$ \\
\hline
\end{tabular}

a) Swedish Environmental Emission Data (2006). b) Geological Survey of Sweden (2014). c) Four rain gauge stations and two measurement stations for other meteorological parameters. Solar radiation was generated by the SWAT weather database provided in the software.

\subsection{Scenarios}

We used hydrological modelling as a tool for characterising the mitigation measures with six different scenarios in total. Two scenarios simulated a high and a low prevalence situation for Cryptosporidium spp. (the E. coli concentrations were kept at the same level for both the high and low prevalence scenarios). Four mitigation scenarios represented possible mitigation measures for the catchment area that were aimed at reducing the Cryptosporidium spp. and E. coli concentrations from both point and non-point sources.

In this study, Cryptosporidium spp. refers to all Cryptosporidium species, not just those that infect humans. When a concentration is considered, "Cryptosporidium spp. oocyst" is referred to as "Cryptosporidium". E. coli was considered to be a faecal indicator, present in all faecal sources. All simulated scenarios included both human and animal sources. The human faecal sources took the form of discharges of wastewater from WWTPs and OWTSs. The domestic animal sources took the form of manure from grazing animals (suckler cows, dairy cows, heifers and steers 1-2 years, sheep and horses) and the application of manure as fertiliser (accumulated from the grazing animal categories during 
Accepted version - Final version available: http://dx.doi.org/10.1016/j.jhydrol.2016.11.011

0022-1694/@2016 This version is made available under the CC-BY-NC-ND 4.0 license

indoor periods and all manure accumulated from heifers and steers younger than 1 year, swine and poultry).

\subsubsection{Prevalence scenarios}

Prevalence expresses the proportion of a population that has a certain disease at a specific point in time, whereas incidence is a measure of the new cases of the disease arising during a defined time period (Beaglehole et al., 1993). In the low prevalence scenario, the concentrations of Cryptosporidium in faecal contamination sources were calculated based on literature data on prevalence, incidence and excretion rates among animals and humans. These data were collected in order to produce an estimate and form assumptions. The high prevalence scenario described a hypothetical situation with a prevalence of Cryptosporidium infection among humans set at $50 \%$. This assumption was based on the information that $45 \%$ of exposed people were infected during the waterborne disease outbreak in Östersund in Sweden (Lindberg et al., 2011). In the high prevalence scenario, all animal groups that had a prevalence lower than $50 \%$ in the low prevalence scenario were assigned a prevalence of $50 \%$.

\subsubsection{Mitigation scenarios}

Four different mitigation scenarios (M1-M4) for reducing the effect from contamination sources were modelled. Scenarios $\mathrm{M} 1$ and $\mathrm{M} 2$ simulated a $50 \mathrm{~m}$ vegetative filter strip using the SWAT function "filter strips". In scenario M1, the vegetative filter strip was applied to cropland, and in scenario M2 it was applied to pasture land. The vegetative filter strip function accounted for removal in a densely vegetated strip between the land area and the waterway. This strip intercepts runoff and traps sediment (Nietsch et al., 2011). In scenario M3, all OWTSs were assigned a removal rate of 2 Log10 units for both E. coli and Cryptosporidium, which meant that underperforming OWTSs were restored to full capacity. In scenario M4, removal by the WWTPs was increased by one Log10 unit for both Cryptosporidium and E. coli. All scenarios were simulated between 2003 and 2011, with 2002 as a warm-up period. The effects of the different mitigation scenarios on the simulated maximum daily concentrations of $E$. coli and Cryptosporidium were calculated as Log10 unit reductions with the high prevalence scenario as the baseline scenario.

\subsubsection{Statistical tests}

To estimate whether the reductions of the maximum concentrations due to the mitigation measures were significant, the Wilcoxon signed rank test was used. The maximum daily concentration from each sub-basin in the high prevalence scenario was compared to the maximum daily concentration of each sub-basin in the mitigation scenario. To investigate if there were significant differences between summer and winter concentrations, the Mann-Whitney $U$ test was used. Monthly mean concentrations for summer (April-September) and winter (October-March) in the catchment outflow (sub-basin 35) for the entire simulation period were used. Calculations were performed using IMB SPSS Statistics, version 22.

\subsection{Faecal contamination sources and parameterisation}

In the SWAT model, the function "persistent bacteria" represented Cryptosporidium, and "less persistent bacteria" represented the indicator organism $E$. coli (see parameterisation in Table 2). Growth of both $E$. coli (Ohlsson et al., 2011) and Cryptosporidium (WHO, 2011) was set at zero. 
Accepted version - Final version available: http://dx.doi.org/10.1016/j.jhydrol.2016.11.011

0022-1694/@2016 This version is made available under the CC-BY-NC-ND 4.0 license

Table 2 E. coli and Cryptosporidium attributes in SWAT.

\begin{tabular}{|c|c|c|c|}
\hline Parameter & Unit & $\begin{array}{l}\text { Cryptosporidium spp. } \\
\text { oocysts }\end{array}$ & E. coli \\
\hline $\begin{array}{l}\text { Partitioning coefficient, fraction sorbed to soil } \\
\text { particles or in soil solution }\end{array}$ & - & $0.5^{\mathrm{a}}$ & $0.5^{\mathrm{a}}$ \\
\hline $\begin{array}{l}\text { Soil partitioning coefficient (determines the ratio } \\
\text { between concentration in the top } 10 \mathrm{~mm} \text { of the soil } \\
\text { solution and the concentration in the runoff solution) }\end{array}$ & - & $175^{\mathrm{b}}$ & $90^{c}$ \\
\hline $\begin{array}{l}\text { Manure fraction applied to the top } 10 \mathrm{~mm} \text { of the soil } \\
\text { layer }\end{array}$ & - & $0.1^{\mathrm{a}}$ & $0.1^{\mathrm{a}}$ \\
\hline Die-off, in soil solution & $1 /$ day & $0.03^{b, d}$ & $0.201^{c}$ \\
\hline Die-off, in water bodies & $1 /$ day & $0.01^{b, d}$ & $0.25^{\mathrm{e}}$ \\
\hline Die-off, adsorbed to soil particles & $1 /$ day & $0.003^{b, d}$ & $0.023^{c}$ \\
\hline Die-off, on foliage & 1/day & $0.03^{b, d}$ & $0.016^{c}$ \\
\hline $\begin{array}{l}\text { Wash-off fraction (organisms washed off in rainfall } \\
\text { events) }\end{array}$ & - & $0.005^{f}$ & $0.013^{f}$ \\
\hline
\end{tabular}

a) Estimation based on values reported by Coffey et al. (2010b) (0.9) and Tang et al. (2011) (0.2) b) Coffey et al. (2010a) c) Bougeard et al. (2011b) d) Dorner et al. (2006) e) Sokolova et al. (2012) f) Ferguson et al. (2007a).

\subsubsection{Discharges of municipal wastewater}

Nine WWTPs that serve more than 2000 persons each were defined in the model (Figure 2). The mean daily discharges from these WWTPs varied between 510 and $57,100 \mathrm{~m}^{3}$ per day. The data for mean daily discharges for either 2012 or 2013 were obtained for each WWTP. WWTP discharge was entered into the model as a constant discharge with a constant concentration over the simulation period. Due to the absence of data, discharges from the sewer network, such as combined sewer overflows, were not included in the model.

The $E$. coli concentration in treated wastewater from WWTPs was estimated to be $1.0 \mathrm{E} 4 \mathrm{E}$. coli/100 ml, based on reported mean concentrations (1.5E6 E. coli/100 mL) in incoming wastewater (Ohlsson et al., 2011) and reported removal (2.4 Log10 units) in the wastewater treatment plant (Ottoson et al., 2006).

The Cryptosporidium spp. prevalence in humans, for the low prevalence scenarios was calculated using Equation 1.

$$
P_{h}=\frac{I * U * D}{365 * 100,000 *\left(1-\mathrm{A}_{i}\right)}
$$

where $P_{h}$ is the prevalence in humans, $l$ is the geometric mean of incidence (per year $/ 100,000$ inhabitants), $U$ is the factor of underreporting, $D$ is the number of days when excretion occurs during infection and $A_{i}$ is the proportion of asymptomatic infections. 
Accepted version - Final version available: $\underline{\mathrm{http}} / / / \mathrm{dx}$.doi.org/10.1016/j.jhydrol.2016.11.011

0022-1694/@2016 This version is made available under the CC-BY-NC-ND 4.0 license

The low prevalence scenario was described using the data from the Public Health Agency of Sweden as a geometric mean of incidence for the Stockholm and Uppsala regions between 2004 and 2011 (3.18 infections per year per 100,000 inhabitants). The factor for underreporting was conservatively assumed to be 38 (Mead et al., 1999), the proportion of asymptomatic infections was assumed to be 0.29 (Havelaar and Melse, 2003) and the excretion time was assumed to be 10 days (Smith et al., 1995).

The Cryptosporidium concentration in treated wastewater from WWTPs was calculated using Equation 2.

$$
C_{\text {Crypto }}=\frac{P_{h * F * E}}{\mathrm{~W} * 10^{r}}
$$

where $C_{\text {crypto }}$ is the Cryptosporidium concentration in the outgoing wastewater from WWTPs, $F$ is the faecal production per person per day, $E$ is the Cryptosporidium concentration in human faeces from infected individuals, $W$ is the wastewater discharge per person per day, and $r$ is the Log10 removal at the WWTP. The following assumptions were made: the faecal production is $1.5 \mathrm{E} 2 \mathrm{~g} /$ person/day (Stephen and Cummings, 1980; Wyman et al., 1978), the concentration in faecal matter from an infected person is $1.0 \mathrm{E} 7$ oocysts/g (Gerba, 2000), wastewater discharge is 360L/person/day (based on local mean daily discharges), and the removal rate in the WWTP is 1.3 Log10 units (Ottoson et al., 2006).

The Cryptosporidium concentrations in treated wastewater were assumed to be $9.7 \mathrm{E}-1$ oocysts $/ 100 \mathrm{ml}$ for the low prevalence scenario and $1.0 \mathrm{E} 4$ oocysts $/ 100 \mathrm{~mL}$ for the high prevalence scenario.

\subsubsection{On-site wastewater treatment systems}

As the exact locations of OWTSs were unknown, the property map was used, assuming that each property outside urban areas contained one OWTS and that the OWTS was located in the center of the property. OWTSs (in total 17,286) were classified as sand filter $(1,210)$, infiltration $(7,087)$, closed tank $(2,074)$ or septic tank only/unknown $(6,915)$ based on proportions reported for the region (Swedish Environmental Protection Agency, 2004). In the absence of data related to their location and functionality, the OWTSs in the model were defined using the function "continuous fertilisation", as adopted by Coffey et al. (2010b). The contribution from OWTSs was thus expressed as $\mathrm{kg} / \mathrm{ha} / \mathrm{day}$. The assumptions made were that wastewater discharge is $1.60 \mathrm{E} 2 \mathrm{~L} /$ person/day, that there are 2.5 persons/property, that $1 \mathrm{~L}$ wastewater corresponds to $1 \mathrm{~kg}$ (Coffey et al., 2010b), and that the contribution from each property is spread over an area of 1 ha.

The $E$. coli concentrations in the discharges from OWTSs were calculated based on the assumed $E$. coli concentration in untreated domestic wastewater (1E7 E. coli/100 ml) (Arnold et al., 2012b) and the general information on the reduction by different OWTSs: sand filter $95 \%$, infiltration $99 \%$, closed tanks $100 \%$, unknown type $50 \%$. The Cryptosporidium concentrations in untreated domestic wastewater were calculated in the manner described above for municipal wastewater. The reduction in Cryptosporidium by OWTSs was assumed to be the same as for E. coli. Cryptosporidium concentrations in untreated domestic wastewater were recalculated to amounts per gram for the "continuous fertilisation" operation. Given the classification of OWTSs and the general removal rate in different OWTSs, the overall concentration of Cryptosporidium was assumed to be $1.94 \mathrm{E}-1 / \mathrm{g}$ for the low prevalence scenario and $2.08 \mathrm{E} 5 / \mathrm{g}$ for the high prevalence scenario. 
Accepted version - Final version available: http://dx.doi.org/10.1016/j.jhydrol.2016.11.011

0022-1694/@2016 This version is made available under the CC-BY-NC-ND 4.0 license

\subsubsection{Domestic animals}

Horses, suckler cows, dairy cows, heifers and steers 1-2 years and sheep were assumed to graze for 274, $97,137,177$, and 152 days respectively during the summer, and that they evenly occupy all areas classified as pasture throughout the season (The number of animals is reported in Table 3). Grazing periods for suckler cows, dairy cows and heifers and steers 1-2 years were based on reported grazing periods (Statistics Sweden, 2012) and the grazing period for horses and sheep was based on an estimate. The amount of manure produced during these periods was entered into the model using the function "grazing operation".

Manure produced by horses, suckler cows, heifers and steers 1-2 years, dairy cows and sheep during indoor periods, and all manure produced by swine, poultry and heifers and steers younger than 1 year, was assumed to be stored and applied as fertiliser. This was specified in the model using the SWAT function "fertiliser application". It has been shown that $E$. coli concentrations are reduced during manure storage (Klein et al., 2010) and that Cryptosporidium parvum oocysts are inactivated by ammonia, which is commonly present in manure (Jenkins et al., 1998). Even so, since the purpose of the simulation was to estimate the effects of mitigation measures, it was assumed that there is no reduction in E. coli and Cryptosporidium concentrations during manure storage. Manure was distributed evenly over areas classified as cropland, divided evenly over four days each year: April 15th, July 1st, September 15th and October 15th. The manure dose was calculated using Equation 3:

$$
D=\frac{\sum_{i=1}^{n} \mathrm{~V}_{i} * \mathrm{~N}_{i} * \mathrm{~T}_{i}}{4 * \mathrm{~A}}
$$

where $D$ is the manure dose, $V_{i}$ is the manure production per day for each domestic animal category $(i=1 \ldots n), N_{i}$ is the number of animals of each animal category in the area, $T_{i}$ is the number of days for manure accumulation each year and $A$ is the total manure application area in the catchment area.

Assumptions regarding the prevalence of Cryptosporidium spp. in domestic animal categories were made in order to state the different concentrations of Cryptosporidium spp. oocyst in faeces for the low and high prevalence scenarios (Table 3). Excretion rates of Cryptosporidium spp. oocyst from animals and humans varies between individuals and are not constant during the course of the infection (Chappell et al., 1996; Xiao and Herd, 1994). Nonetheless, in order to estimate concentrations of Cryptosporidium spp. oocyst in faeces, excretion rates were assumed to be the same. The assumptions regarding prevalence and excretion rates in domestic animals, as well as the number of domestic animals in the area, were combined in order to calculate the mean concentration of Cryptosporidium in manure (Table 3). The mean concentration of Cryptosporidium in manure for the low and high prevalence scenarios was calculated using Equation 4:

$$
\mathrm{C}_{g}=\frac{\sum_{i=1}^{n} \mathrm{C}_{i} * \mathrm{P}_{i} * \mathrm{~V}_{i} * \mathrm{~N}_{i} * \mathrm{~T}_{i}}{\sum_{i=1}^{n} \mathrm{~V}_{i} * \mathrm{~N}_{i} * \mathrm{~T}_{i}}
$$

where $C_{g}$ is the mean Cryptosporidium concentration in manure, $C_{i}$ is the excretion rate of infected animals, $P_{i}$ is the prevalence, $V_{i}$ is the manure production per day, $N_{i}$ is the number of animals in the area, $T_{i}$ is the number of days for manure accumulation each year and $i$ represents the different domestic animal categories $(i=1 \ldots n)$. 
Studies referred to in Table 3 were not designed solely for determining the overall prevalence regarding each specific animal type and nor were any of these studies specifically designed to be used to provide this type of input for modelling. Hence, the adopted parameters (Table 3) are mere examples of possible Cryptosporidium concentrations rather than local catchment area data. Even so, these assumptions were made in order to provide the possibility of evaluating the effects of the mitigation measures on the Cryptosporidium concentrations. It should be noted that poultry does not contribute to the Cryptosporidium concentrations, only the E. coli concentration.

Table 3 Input data for the manure load that include the number of animals in the catchment area, the prevalence, the excretion rate and the mean microbial concentrations in manure based on prevalence assumptions.

\begin{tabular}{|c|c|c|c|c|c|c|c|}
\hline & \multirow{2}{*}{$\begin{array}{l}\text { Manure } \\
\left(\text { kg animal }^{-1}\right. \\
\left.\text { day }^{-1}\right)\end{array}$} & \multirow[t]{2}{*}{$\begin{array}{l}\text { Animals } \\
(2010)\end{array}$} & \multirow{2}{*}{$\begin{array}{c}\text { Low } \\
\text { prevalence } \\
\text { scenario } \\
\text { (\% positive) }\end{array}$} & \multirow{2}{*}{$\begin{array}{l}\text { Excretion } \\
\text { rate } \\
\left(\text { oocyst g }^{-1}\right)\end{array}$} & \multicolumn{2}{|c|}{$\begin{array}{l}\text { Cryptosporidium spp. } \\
\left.\text { (oocysts } g^{-1}\right)\end{array}$} & \multirow{2}{*}{$\begin{array}{c}\text { E. coli } \\
(\text { E.coli } \\
\left.\mathrm{g}^{-1}\right)\end{array}$} \\
\hline & & & & & $\begin{array}{l}\text { Low prev. } \\
\text { scenario }\end{array}$ & $\begin{array}{l}\text { High prev. } \\
\text { scenario }\end{array}$ & \\
\hline $\begin{array}{l}\text { Suckler } \\
\text { cows }\end{array}$ & $16.0^{a}$ & 4,650 & $5.6^{b}$ & $5.0 \mathrm{E} 2^{\mathrm{h}}$ & 28 & $2.5 \mathrm{E} 2$ & $2.0 \mathrm{E}^{\mathrm{C}}$ \\
\hline Sheep & $2.2^{\mathrm{a}}$ & 10,930 & $12.7^{d}$ & $2.8 \mathrm{E} 3^{\mathrm{h}}$ & $3.56 \mathrm{E} 2$ & $1.4 \mathrm{E} 3$ & $2.0 \mathrm{E} 7^{\mathrm{C}}$ \\
\hline Swine & $3.8^{\mathrm{a}}$ & 17,304 & $32^{\mathrm{e}}$ & $1.0 \mathrm{E} 6^{\mathrm{h}}$ & $3.2 \mathrm{E} 5$ & $5.0 \mathrm{E} 5$ & $3.0 \mathrm{E} 6^{\mathrm{C}}$ \\
\hline Horses & $13.7^{a}$ & 4,753 & $0^{f}$ & $2.07 \mathrm{E} 3^{\mathrm{h}}$ & 0 & $1.035 \mathrm{E} 3$ & $1.0 \mathrm{E} 4^{\mathrm{C}}$ \\
\hline $\begin{array}{l}\text { Heifers } \\
\text { and steers } \\
<1 \text { year }\end{array}$ & $7.4^{\mathrm{a}}$ & 6,525 & $52^{b}$ & $1.0 \mathrm{E} 6^{\mathrm{h}}$ & $5.2 \mathrm{E} 5$ & $5.2 \mathrm{E} 5$ & $2.0 \mathrm{E}^{\mathrm{C}}$ \\
\hline $\begin{array}{l}\text { Heifers } \\
\text { and steers } \\
1-2 \text { years }\end{array}$ & $11.9^{a}$ & 5,055 & $29^{b}$ & $1.0 \mathrm{E} 4^{\mathrm{h}}$ & $2.9 \mathrm{E} 3$ & 5.0 E3 & $2.0 \mathrm{E} 5^{\mathrm{C}}$ \\
\hline $\begin{array}{l}\text { Dairy } \\
\text { cows }\end{array}$ & $29.2^{\mathrm{a}}$ & 4,106 & $5.6^{\mathrm{b}}$ & $5.0 \mathrm{E} 2^{\mathrm{h}}$ & 28 & $2.5 \mathrm{E} 2$ & $2.0 \mathrm{E} 5^{\mathrm{C}}$ \\
\hline Poultry & $\begin{array}{l}0.1 \text { (per } \\
100 \\
\text { animals) }^{a}\end{array}$ & 85,452 & $0^{g}$ & $0^{\text {h }}$ & 0 & 0 & $1.0 \mathrm{E}^{\mathrm{C}}$ \\
\hline
\end{tabular}

a) Based on the manure storage requirements presented in Eskilsson (2013) b) Silverlås et al. (2009) c) Stenström et al. (1980) d) Robertson et al. (2010) e) Langkjær et al. (2007) f) Hamnes (2008) g) Cox et al. (2005) h) Estimate within the excretion rate ranges reported in b, d, e, f, and g. 
Accepted version - Final version available: http://dx.doi.org/10.1016/j.jhydrol.2016.11.011

0022-1694/@2016 This version is made available under the CC-BY-NC-ND 4.0 license

\subsection{Model evaluation}

The performance of the SWAT model was evaluated using the Nash-Sutcliffe Efficiency index (NSE) and the coefficient of determination $\left(R^{2}\right)$. Even though both $R^{2}$ and NSE have a certain bias towards high flows (Arnold et al., 2012a), they were chosen on the basis of their frequent use for evaluating hydrological models. Parajuli (2007) suggested the following performance index for NSE, adopted from Moriasi et al. (2007): Unsatisfactory (<0), Poor (0-0.24), Fair (0.25-0.49), Good (0.5-0.74), Very good (0.75-0.89) and Excellent ( $\geq 0.9)$.

To calibrate the model for water flow, the SWAT-CUP version 5.1.6.2 GLUE process was used. Calibration and validation were performed on a monthly basis for sub-basins 11, 18 and 27 (see Figure 2) for the periods 2003-2007 (60 data points) and 2008-2011 (48 data points) respectively. Calibration and validation were performed using 500 iterations. Figures illustrating the observed versus the simulated water flow and a list of the parameters adjusted in the calibration and their final values can be found in the supplementary material. Due to the lack of microbial monitoring data and the fact that grab samples do not represent the continuous variation over time, no calibration or validation could be performed for E. coli or Cryptosporidium results. The simulated concentrations of $E$. coli were compared to the concentrations measured in 16 grab samples collected from the catchment area outlet between 2002 and 2011.

\section{Results}

\subsection{Water flow calibration and validation}

Calibration resulted in NSE values of $0.46,0.45$ and 0.50 for sub-basins 11,18 and 27 respectively, and the corresponding $R^{2}$ values were $0.47,0.49$ and 0.51 . Validation revealed NSE values of $0.49,0.36$ and 0.45 for sub-basins 11,18 and 27 respectively, and the corresponding $R^{2}$ values were $0.51,0.41$ and 0.47 . The calibration results ranged from fair to good NSE using the suggested index, and validation resulted in a fair index (see also the supplementary material).

\subsection{Prevalence scenarios}

The modelling results for $E$. coli showed that the monthly mean concentrations at the catchment area outlet varied between 1.5E2 and 9.8E2 E. coli/100 ml, with a mean of 4.1E2 (standard deviation 1.7E2) E. coli/100 ml (Figure 3). The corresponding results for Cryptosporidium showed that for the low prevalence scenario, the oocyst concentrations varied between 1.2E-1 and 1.9E1, with a mean of 4.2 (standard deviation 3.6) oocysts $/ 100 \mathrm{ml}$, whereas for the high prevalence scenario, the concentrations varied between 4.1E2 and 1.7E3, with a mean of 8.8E2 (standard deviation 3.0E2) oocysts/100 ml (Figure 3). 


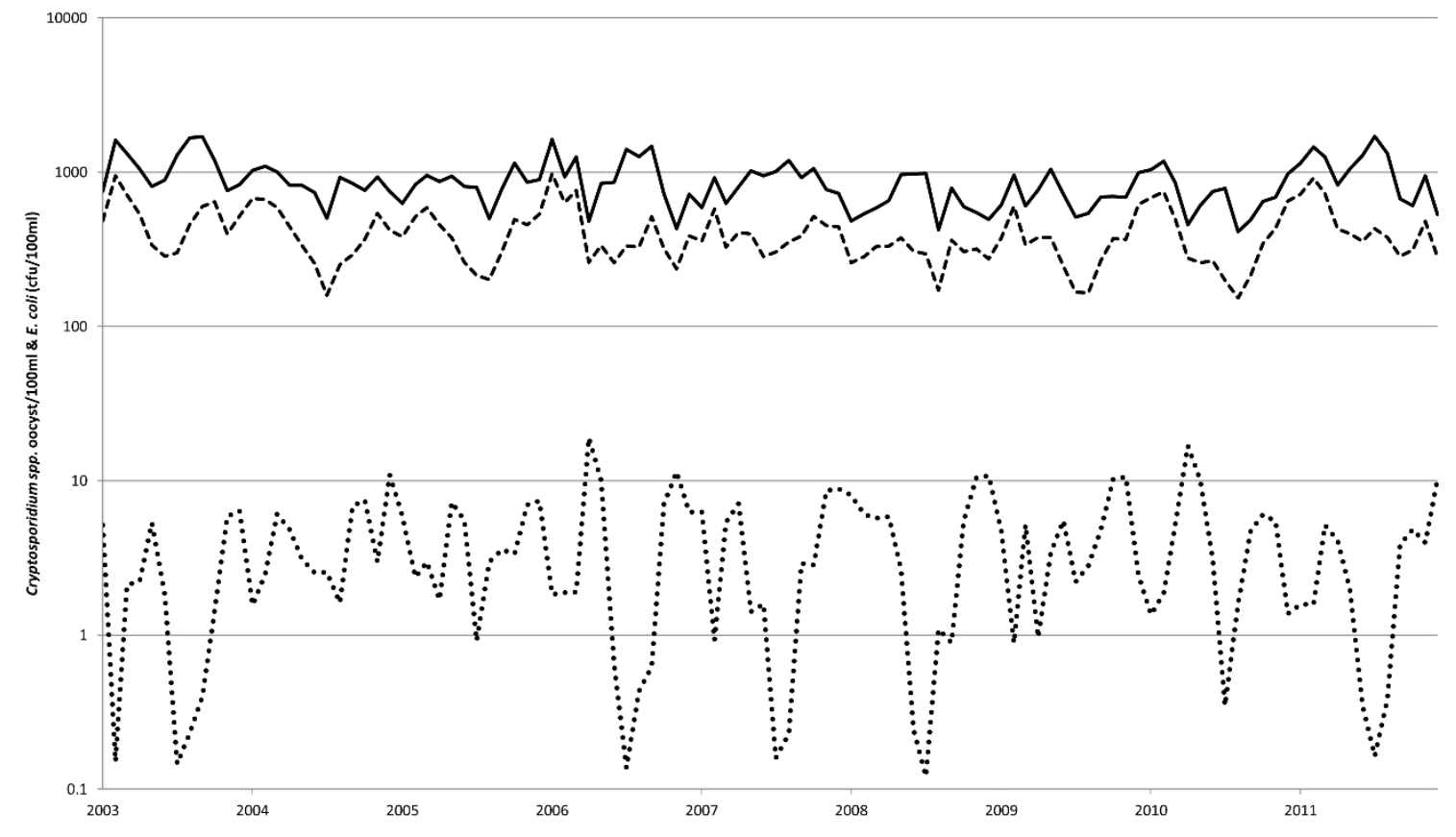

Figure 3 Simulated concentrations of Cryptosporidium and E. coli at the outflow from the Stäket catchment. Solid line - Cryptosporidium concentration for the high prevalence scenario. Dotted line Cryptosporidium concentration for the low prevalence scenario. Dashed line - E. coli concentrations.

\subsection{Mitigation scenarios}

The results for the mitigation scenarios (Figure 4) showed the changes in the contribution from each subbasin due to the different mitigation measures. The results are presented as a Log10 reduction of the maximum daily concentrations of Cryptosporidium and $E$. coli in each sub-basin during the simulated time period, as the maximum concentration represents the risk. For scenario M1 (Figure 4), the reduction in Cryptosporidium concentrations varied between 0 and 0.41 with a mean of 0.16 (standard deviation 0.16 ), while the reduction in E. coli concentrations varied between 0 and 0.46 with a mean of 0.23 (standard deviation 0.17) Log10 units. The reductions in the M1 scenario were significant for $E$. coli and Cryptosporidium concentrations $(\mathrm{p}<0.05)$. The reductions in the $\mathrm{M} 2$ scenario were not significant for E. coli or Cryptosporidium concentrations ( $p>0.05)$. The reductions in the M3 scenario were not significant for $E$. coli $(\mathrm{p}>0.05)$ but significant for Cryptosporidium $(\mathrm{p}<0.05)$ concentrations, although the Log10 reductions were small (average 0.002 Log 10 reduction). The results from scenarios M2 and M3 are reported in Appendix A. For scenario M4 (Figure 4), the Log10 reduction in Cryptosporidium concentrations varied between 0 and 1.0, with a mean of 0.41 (standard deviation 0.45 ), while the reduction in $E$. coli concentrations varied from 0 and 1.0, with a mean of 0.23 (standard deviation 0.33 ) Log10 units. The reductions in the M4 scenario were significant for E. coli and Cryptosporidium concentrations $(p<0.05)$.

For the scenario with the addition of a vegetative filter strip on cropland (M1), the reduction in concentrations was higher for E. coli than for Cryptosporidium. For this scenario (M1), the highest 
reduction was seen in the sub-basins that were unaffected by the WWTP effluents (sub-basins 2, 6-7, 9$11,13-15,17-20,22,29,32$ and 34). For the scenario with increased removal of microorganisms at WWTPs (M4), the reduction in concentrations was higher for Cryptosporidium than for E. coli. For this scenario (M4), the highest reduction was seen in the sub-basins that contained a WWTP or were located downstream of a WWTP (sub-basins 1, 3-5, 8, 12, 16, 21, 23-28, 30-31, 33 and 35).

In the catchment area outflow (sub-basin 35), only scenario M4 resulted in a noticeable reduction in $E$. coli and Cryptosporidium concentrations, while the other scenarios achieved small reductions that were less than 0.005 Log 10 units.

a)
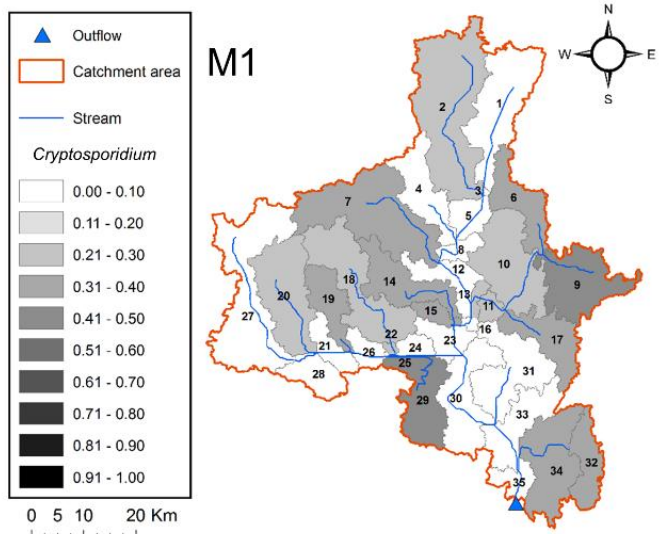

b)
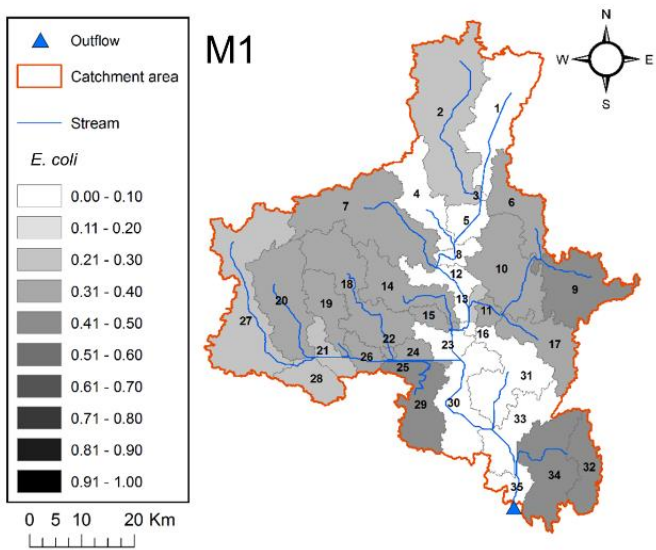
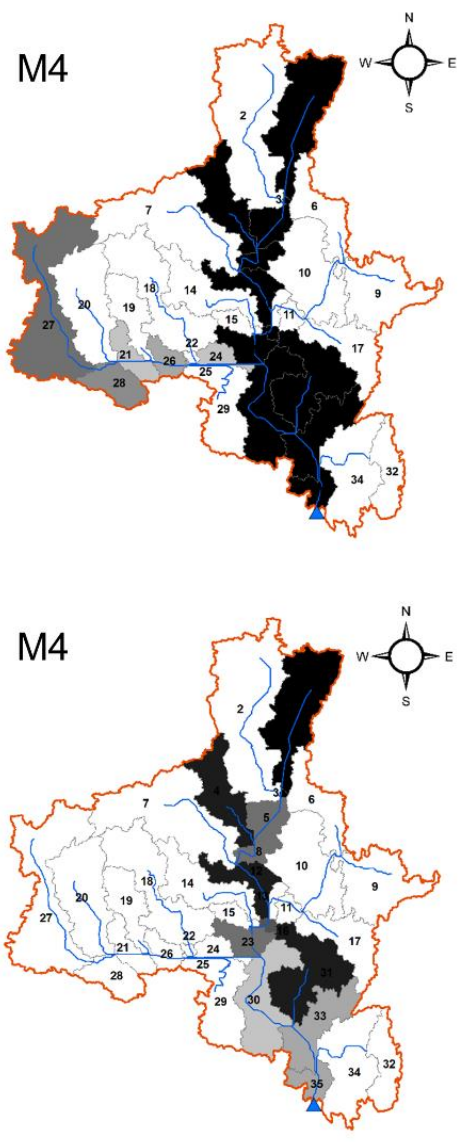

Figure 4 Log10 reduction of maximum (a) Cryptosporidium and (b) E. coli concentration in the different sub-basins for mitigation scenarios M1 (left) and M4 (right). M1 - vegetative filter strip was added to manure application areas. M4 - removal of both Cryptosporidium and E. coli at the wastewater treatment plants was increased by one Log10 unit.

\section{Discussion}

Microbial risk management in drinking water systems requires an understanding of the impact of faecal sources and hydrological conditions within the catchment area. In this paper, hydrological modelling was evaluated in the context of a risk management framework, using Cryptosporidium and E. coli as reference microorganisms. 
Accepted version - Final version available: $\underline{\mathrm{http}} / / / \mathrm{dx}$.doi.org/10.1016/j.jhydrol.2016.11.011

0022-1694/@2016 This version is made available under the CC-BY-NC-ND 4.0 license

The obtained modelling results facilitate the investigation of seasonal variations and comparison of the efficiency of different mitigation measures relative to each other. However, the model output in terms of absolute concentrations should be interpreted with caution. This is due to the limited (fair to good NSE index) model performance of the hydrological component, the fact that calibration and validation of the water quality component were not possible, the scarcity of data needed to characterise the pathogen load in the Stäket catchment area, and some other limitations discussed below.

The modelling results showed that there are seasonal variations in E. coli and Cryptosporidium concentrations (Figure 3). The concentrations of E. coli and Cryptosporidium in the low prevalence scenario were higher during the cold period (October - March) than during the warm period (April September) $(\mathrm{p}<0.05)$. For Cryptosporidium concentrations in the high prevalence scenario the seasonal difference was not significant ( $p>0.05$ ). In brief, the high prevalence scenario is deviating from the seasonal pattern due to that WWTPs are the dominating contamination source and the relative increase in prevalence, from the low to the high prevalence scenario, is larger for the human sources compared to the domestic animal sources, thus generating a high concentration throughout the year. Seasonal variations have been reported in other modelling studies dealing with faecal coliforms (Jayakody et al., 2014) and Cryptosporidium (Coffey et al., 2010b). The seasonal variations can be explained by the temperature-dependent die-off and by the fact that the concentrations can vary as a function of water flow (Coffey et al., 2010a).

The comparison of the simulated concentrations with measured data was limited due to the lack of microbial measurements in the catchment area. When a comparison was made with the results of the routine grab sampling at the catchment area outflow (16 samples collected between 2002 and 2011), the measured $E$. coli concentrations ( $1-17$ colony-forming units (CFU)/100 ml) were lower than the simulated concentrations (1.5E2 - 9.8E2 E. coli/100 ml) (Figure 3). The simulated concentrations of E. coli from other modelling studies can provide a frame of reference but, given that every catchment area is unique, they cannot be compared directly with our results. Bougeard et al. (2011a) reported simulated $E$. coli concentrations in the range 6.0E1 - 1.4E4 CFU/100 ml, Bougeard et al. (2011b) reported the range 7.9E1 - 1.6E5 CFU/100 ml, and Coffey et al. (2012) reported the range $0-6.0 \mathrm{E} 2 \mathrm{CFU} / 100 \mathrm{ml}$. The simulated $E$. coli concentrations in the present study were thus in the same range as the concentrations reported by other modelling studies. Coffey et al. (2010b) reported Cryptosporidium concentrations in the range $4.0 \mathrm{E}-4-4.8 \mathrm{E}-1$, with a mean of $9.0 \mathrm{E}-2$ oocysts $/ 100 \mathrm{ml}$, while Tang et al. (2011) reported Cryptosporidium concentrations in the range $0-4$ oocysts $/ 100 \mathrm{ml}$. Even though the simulated Cryptosporidium concentrations (1.2E-1 - 1.9E1 oocysts/100 $\mathrm{ml}$ ) in the low prevalence scenario of the present study (Figure 3) fall partly within the ranges reported by Tang et al. (2011) and Coffey et al. (2010b), these results should not be compared, since there are fundamental differences in the local settings and the assumptions made regarding input data.

Modelling the fate and transport of faecal contamination has a number of limitations, such as parameter uncertainties (Cho et al., 2012), temporal (Jayakody et al., 2014) and prevalence (Ferguson et al., 2009) variations in pathogen load, as well as the lack of input data (Bougeard et al., 2011b; Coffey et al., 2012). The factors that contribute to the lack of microbial data are the cost and the complexity of the 
Accepted version - Final version available: $\underline{\mathrm{http}} / / / \mathrm{dx}$.doi.org/10.1016/j.jhydrol.2016.11.011

0022-1694/@2016 This version is made available under the CC-BY-NC-ND 4.0 license

monitoring and measurement techniques. In the model of the Stäket catchment area, the use of annual data to define the daily discharges from the WWTPs implied that short-term variations were ignored. Furthermore, removal processes that occur in large water bodies in the Stäket catchment area were not included due to the lack of data for the extensive parameterisation of these processes in the SWAT model. In addition, microbial decay during manure storage was not accounted for. These simplifications contributed to the overestimation of the simulated concentrations. Another potential limitation of this model application is that the contributions from OWTSs were entered into the model using the "continuous fertilisation" function, as suggested by Coffey et al. (2010b). This simplification does not account for the fact that some OWTSs (e.g. OWTS using sand filtration) could be characterised as point sources rather than non-point sources. It would be beneficial to improve the SWAT model by making it possible to simulate different types of OWTSs in combination with different types of microbial contamination. Further improvements to the SWAT model would be to incorporate UV radiation as a removal process, since it is presently not included (Cho et al., 2012), and to include a probabilistic dimension in order to describe uncertainties and possible variations.

Should this type of modelling be used in risk analysis, the prevalence in different animal species and categories needs to be investigated and adapted to the local settings. In the case of Cryptosporidium, the data used as input for microbial risk analysis should only consider the species that can infect humans, e.g. C. hominis and C. parvum. However, due to technical difficulties and the associated high costs, drinking water producers in Sweden have up until now mainly analysed Cryptosporidium concentrations without identification of different species. Currently, there is a general lack of information on the prevalence and excretion rates of zoonotic Cryptosporidium species (Dufour et al., 2012). Nonetheless, using the genus classification of Cryptosporidium in the modelling is useful in order to compare the relative effects of different mitigation measures. If sufficient and accurate data on pathogenic species are available, hydrological modelling can provide useful decision support within the risk management framework (Figure 1).

In order to provide proper decision support to mitigate microbial risks in drinking water systems, different modelling approaches need to be combined (Oliver et al., 2016). Moreover, mitigation measures and management practices need to be integrated into a wider framework (Oliver et al., 2016). In this context, hydrological modelling and monitoring (Burnet et al., 2014; Swaffer et al., 2014) can be seen as important tools. The suggested framework (Figure 1 ) in this paper places hydrological modelling in the broader context of microbial risk management, and is thus a step towards this charted future. Furthermore, to improve hydrological modelling, increased knowledge of the following is needed: (i) occurrence and behaviour of faecal indicators and pathogens in environmental systems, (ii) groundwater contribution to faecal contamination, (iii) uncertainty analysis of the model output, and (iv) model performance on different geographic scales (Oliver et al., 2016).

To be able to include the entire drinking water system and to utilise all parts of the framework, it is important to combine fate and transport modelling, QMRA, and CBA. This paper shows that the SWAT model can characterise different mitigation measures and their effect on indicator and pathogen concentrations. A reduction in pathogen concentrations achieved through different mitigation measures 
Accepted version - Final version available: http://dx.doi.org/10.1016/j.jhydrol.2016.11.011

0022-1694/@2016 This version is made available under the CC-BY-NC-ND 4.0 license

can be used in QMRA to estimate health benefits. Monetisation of these health benefits is an essential element in the CBA part of the suggested framework. The framework provides a map of how each tool can be used in risk management and a structure for combining different tools in order to create decision support. Future research will focus on using the suggested framework to perform CBA based on input from fate and transport modelling in order to present a suitable decision support platform.

\section{Conclusions}

In this study, we used the hydrological SWAT model to simulate the effect of mitigation measures on $E$. coli and Cryptosporidium spp. oocyst concentrations in the catchment area of a drinking water source. Hydrological modelling integrated into the presented risk management framework provides important decision support regarding the implementation of mitigation measures aimed at reducing the health risks.

The following conclusions were drawn:

- Vegetative filter strips in conjunction with cropland (scenario M1) and increasing the removal rate at the wastewater treatment plants (scenario M4) were the two mitigation measures that achieved a significant reduction ( $\mathrm{p}<0.05$ ) in both Cryptosporidium and $E$. coli concentrations.

- Increasing the removal rate at the wastewater treatment plants (scenario M4) was the mitigation measure that resulted in the highest microbial reduction at the catchment area outflow.

- The SWAT model could be applied to simulate the different mitigation measures and their ability to reduce Cryptosporidium and E. coli concentrations.

- The use of hydrological modelling for further risk analysis would require more information on pathogen prevalence, excretion rates and behaviour in the environment.

- Hydrological modelling, as performed in this study, could be a key component in facilitating monetisation of health benefits from reduced microbial risks.

Quantitative microbial risk assessment based on fate and transport modelling results can help estimate the health effects achieved by different mitigation measures. Monetisation of the health effects and cost-benefit analysis facilitate comparison between the mitigation measures and constitute important decision support to ensure efficient use and prioritisation of efforts and resource allocation. Fate and transport modelling is thus an important tool that will ultimately provide economic decision support in accordance with the risk management framework suggested in this paper.

\section{Acknowledgements}

The study was conducted within DRICKS - Framework programme for drinking water research at Chalmers University of Technology. This study was part of the project Risk-Based Decision Support for Safe Drinking Water (RiBS) funded by the Swedish Water and Wastewater Association (SWWA, project 13-102). We are also grateful for assistance provided in the development of scenarios and for information regarding input data for the modelling provided by the group members within the project Geographic Information Systems (GIS) as a base for transport modelling of parasitic sources in surface waters (SWWA project 13-123), funded jointly by SWWA and the Sven Tyréns Foundation. 
Accepted version - Final version available: http://dx.doi.org/10.1016/j.jhydrol.2016.11.011

0022-1694/@2016 This version is made available under the CC-BY-NC-ND 4.0 license

\section{References}

Arnold, J. et al., 2012a. SWAT: Model use, calibration, and validation. Transactions of the ASABE, 55(4): 1491-1508.

Arnold, J.G. et al., 2012b. Soil \& Water Assessment Tool, Input/Output Dokumentation, Version 2012, Texas Water Resources Institute.

Åström, J., 2013. Geographic information systems for the analysis of parasitic sources in surface waters, Svenskt Vatten $A B$, Stockholm.

Åström, J., Pettersson, T.J.R., 2010. Technical efficiency of existing risk reduction options in surface water systems. TECHNEAU, Deliverable no. D 4.3.3.

Aven, T., 2012. Foundations of Risk Analysis (2nd Edition). John Wiley \& Sons, Hoboken, NJ, USA.

Baffoe-Bonnie, B., Harle, T., Glennie, E., Dillon, G., Sjøvold, F., 2008. Framework for operational cost benefit analysis in water supply. TECHNEAU, Deliverable no. D 5.1.2.

Beaglehole, R., Bonita, R., Kjellström, T., Ebrary, 1993. Basic epidemiology. World Health Organization, Geneva.

Booty, W., Benoy, G., 2009. Multicriteria Review of Nonpoint Source Water Quality Models for Nutrients, Sediments, and Pathogens. Water Quality Research Journal of Canada, 44(4): 365-377.

Bougeard, M. et al., 2011a. Modeling of Escherichia coli Fluxes on a Catchment and the Impact on Coastal Water and Shellfish Quality. JAWRA Journal of the American Water Resources Association, 47(2): 350-366. DOI:10.1111/j.1752-1688.2010.00520.x

Bougeard, M. et al., 2011b. Combining modeling and monitoring to study fecal contamination in a small rural catchment. Journal of Water and Health, 9 (3): 467-482. DOI:10.2166/wh.2011.189

Burnet, J.-B., Penny, C., Ogorzaly, L., Cauchie, H.-M., 2014. Spatial and temporal distribution of Cryptosporidium and Giardia in a drinking water resource: Implications for monitoring and risk assessment. Science of The Total Environment, 472: 1023-1035.

DOI:http://dx.doi.org/10.1016/i.scitotenv.2013.10.083

Centers for Disease Control and Prevention (2014a, 2 November 2010). "Parasites - Cryptosporidium Biology." Retrieved 27 January, 2014, from http://www.cdc.gov/parasites/crypto/biology.html.

Centers for Disease Control and Prevention (2014b, 2 November 2010). "Parasites - Infection - General public." Retrieved 27 January, 2014, from http://www.cdc.gov/parasites/crypto/gen info/infect.html.

Chappell, C.L., Okhuysen, P.C., Sterling, C.R., DuPont, H.L., 1996. Cryptosporidium parvum: intensity of infection and oocyst excretion patterns in healthy volunteers. Journal of Infectious Diseases, 173(1): 232-236.

Cho, K.H., Pachepsky, Y.A., Kim, J.H., Kim, J.-W., Park, M.-H., 2012. The modified SWAT model for predicting fecal coliforms in the Wachusett Reservoir Watershed, USA. Water Research, 46(15): 4750-4760. DOI:http://dx.doi.org/10.1016/j.watres.2012.05.057

Coffey, R., Cummins, E., 2008. Evaluation of current approaches to modelling microbial contamination of catchments, ESAI Colloquium Proceedings 2007, pp. 22.

Coffey, R., Cummins, E., Bhreathnach, N., Flaherty, V.O., Cormican, M., 2010a. Development of a pathogen transport model for Irish catchments using SWAT. Agricultural Water Management, 97(1): 101-111. DOI:http://dx.doi.org/10.1016/j.agwat.2009.08.017 
Accepted version - Final version available: http://dx.doi.org/10.1016/j.jhydrol.2016.11.011

0022-1694/@2016 This version is made available under the CC-BY-NC-ND 4.0 license

Coffey, R., Cummins, E., Flaherty, V.O., Cormican, M., 2010b. Analysis of the soil and water assessment tool (SWAT) to model Cryptosporidium in surface water sources. Biosystems Engineering, 106(3): 303-314. DOI:http://dx.doi.org/10.1016/j.biosystemseng.2010.04.003

Coffey, R., Cummins, E., O' Flaherty, V., Cormican, M., 2010c. Pathogen Sources Estimation and Scenario Analysis Using the Soil and Water Assessment Tool (SWAT). Human and Ecological Risk Assessment: An International Journal, 16(4): 913-933. DOI:10.1080/10807039.2010.502051

Coffey, R., Dorai-Raj, S., O'Flaherty, V., Cormican, M., Cummins, E., 2012. Modeling of Pathogen Indicator Organisms in a Small-Scale Agricultural Catchment Using SWAT. Human and Ecological Risk Assessment: An International Journal, 19(1): 232-253. DOI:10.1080/10807039.2012.701983

Cox, P., Griffith, M., Angles, M., Deere, D., Ferguson, C., 2005. Concentrations of pathogens and indicators in animal feces in the Sydney watershed. Applied and environmental microbiology, 71(10): 5929-5934.

Dorner, S.M., Anderson, W.B., Slawson, R.M., Kouwen, N., Huck, P.M., 2006. Hydrologic modeling of pathogen fate and transport. Environmental science \& technology, 40(15): 4746-4753.

Dufour, A.P., Dufour, A., Organization, W.H., 2012. Animal waste, water quality and human health. IWA Publishing.

Eskilsson, J., 2013. Manure and Environment 2014, Swedish Board of Agriculture, Jönköping, Sweden.

Ferguson, C. et al., 2007a. Field scale quantification of microbial transport from bovine faeces under simulated rainfall events. Journal of water and health, 5(1): 83-95.

Ferguson, C.M., Charles, K., Deere, D.A., 2009. Quantification of Microbial Sources in Drinking-Water Catchments. Critical Reviews in Environmental Science and Technology, 39(1): 1-40. DOI:10.1080/10643380701413294

Ferguson, C.M., Croke, B.F.W., Beatson, P.J., Ashbolt, N.J., Deere, D.A., 2007b. Development of a processbased model to predict pathogen budgets for the Sydney drinking water catchment. Journal of Water and Health, 5(2): 187-208. DOI:10.2166/wh.2007.013

Geological Survey of Sweden, 2014. Soil map, quaterny deposits.

Gerba, C.P., 2000. Assessment of enteric pathogen shedding by bathers during recreational activity and its impact on water quality. Quantitative Microbiology, 2(1): 55-68.

Hamnes, I.S., 2008. Cryptosporidium and Giardia in selected domestic and wild animal species in Norway. Ph.D. Thesis Thesis, Norwegian School of Veterinary Science Unipub, Oslo, Norway.

Hansen, A., 2011. Giardia and Cryptosporidium in Swedish surface water sources, Smittskyddsinstitutet, Stockholm.

Havelaar, A., Melse, J., 2003. Quantifying public health risk in the WHO Guidelines for drinking-water quality: A burden of disease approach. RIVM report 734301022/2003, World Health Organisation, Bilthoven.

ISO, I., 2009. Risk management-Principles and guidelines. ISO 31000:2009, Geneva, Switzerland.

Jayakody, P., Parajuli, P.B., Brooks, J.P., 2014. Evaluating spatial and temporal variability of fecal coliform bacteria loads at the Pelahatchie watershed in Mississippi. Human and Ecological Risk Assessment: An International Journal, 20(4): 1023-1041.

Jenkins, M.B., Bowman, D.D., Ghiorse, W.C., 1998. Inactivation of Cryptosporidium parvumoocysts by ammonia. Applied and environmental microbiology, 64(2): 784-788. 
Accepted version - Final version available: http://dx.doi.org/10.1016/j.jhydrol.2016.11.011

0022-1694/@2016 This version is made available under the CC-BY-NC-ND 4.0 license

Kim, J.W., Pachepsky, Y.A., Shelton, D.R., Coppock, C., 2010. Effect of streambed bacteria release on E. coli concentrations: Monitoring and modeling with the modified SWAT. Ecological Modelling, 221(12): 1592-1604. DOI:10.1016/j.ecolmodel.2010.03.005

Klein, M. et al., 2010. Diversity and abundance of zoonotic pathogens and indicators in manures of feedlot cattle in Australia. Applied and environmental microbiology, 76(20): 6947-6950.

Langkjær, R.B., Vigre, H., Enemark, H.L., Maddox-Hyttel, C., 2007. Molecular and phylogenetic characterization of Cryptosporidium and Giardia from pigs and cattle in Denmark. Parasitology, 134(03): 339-350.

Lindberg, A., Lusua, J., Nevhage, B., 2011. Cryptosporidium in Östersund during the winter 2010/2011, Consequences and Costs from an Outbreak of a Waterborne Disease. FOI-R--3376--SE, Swedish Defence Research Agency, Stockholm, Sweden.

Lindhe, A., 2010. Risk assessment and decision support for managing drinking water systems. Ph.D. Thesis, Chalmers University of Technology, Göteborg, Sweden.

Lindhe, A., Rosén, L., Norberg, T., Bergstedt, O., 2009. Fault tree analysis for integrated and probabilistic risk analysis of drinking water systems. Water research, 43(6): 1641-1653.

Mead, P.S. et al., 1999. Food-related illness and death in the United States. Emerging infectious diseases, 5(5): 607.

Moriasi, D. et al., 2007. Model evaluation guidelines for systematic quantification of accuracy in watershed simulations. Trans. ASABE, 50(3): 885-900.

Nietsch, S.L., Arnold, J.G., Kiniry, J.R., Williams, J.R., 2011. Soil and Water Assessment Tool - Theoretical documentation - Version 2009. TR-406, Texas Water Resource Institute, Texas.

NZMH, 2014. Water Safety Plan Guides for Drinking Water Supplies. Version 2 (S1-S2, P1-P11, D1-D2, G1G2, W1-W2), Ministry of Health, New Zeeland, Wellington, New Zeeland.

Ohlsson, L., Karlsson, D., Gustafsson, L.-G., 2011. Urban influence on bacterial quality in receiving waters. Nr 2011-08, Swedish Water and Wastewater Association, Stockholm, Sweden.

Oliver, D.M. et al., 2016. Predicting microbial water quality with models: Over-arching questions for managing risk in agricultural catchments. Science of The Total Environment, 544: 39-47. DOI:http://dx.doi.org/10.1016/j.scitotenv.2015.11.086

Ottoson, J. et al., 2006. Removal of noro-and enteroviruses, Giardia cysts, Cryptosporidium oocysts, and fecal indicators at four secondary wastewater treatment plants in Sweden. Water environment research, 78(8): 828-834.

Parajuli, P.B., 2007. SWAT bacteria sub-model evaluation and application. Ph.D. Thesis Thesis, Kansas State University, Manhattan, Kansas, USA

Parajuli, P.B., Mankin, K.R., Barnes, P.L., 2009. Source specific fecal bacteria modeling using soil and water assessment tool model. Bioresource Technology, 100(2): 953-963.

DOI:http://dx.doi.org/10.1016/j.biortech.2008.06.045

Rizak, S. et al., 2003. Drinking water quality management: a holistic approach. Water Science \& Technology, 47(9): 31-36.

Robertson, L., Gjerde, B., Hansen, E.F., 2010. The zoonotic potential of Giardia and Cryptosporidium in Norwegian sheep: a longitudinal investigation of 6 flocks of lambs. Veterinary parasitology, 171(1): 140-145. 
Accepted version - Final version available: http://dx.doi.org/10.1016/j.jhydrol.2016.11.011

0022-1694/@2016 This version is made available under the CC-BY-NC-ND 4.0 license

Rosén, L., Hokstad, P., Lindhe, A., Sklet, S., Røstum, J., 2007. Generic framework and methods for integrated risk management in water safety plans. TECHNEAU, Deliverable no. D 4.1.3.

Silverlås, C., Emanuelson, U., de Verdier, K., Björkman, C., 2009. Prevalence and associated management factors of Cryptosporidium shedding in 50 Swedish dairy herds. Preventive veterinary medicine, 90(3): 242-253.

Smith, H.V., Robertson, L.J., E., O.J., 1995. Cryptosporidiosis and giardiasis - the impact of waterborne transmission. Journal of Water Supply, Research and Technology, 44: 258-274.

Sokolova, E., Åström, J., Pettersson, T.J.R., Bergstedt, O., Hermansson, M., 2012. Decay of Bacteroidales Genetic Markers in Relation to Traditional Fecal Indicators for Water Quality Modeling of Drinking Water Sources. Environmental Science \& Technology, 46(2): 892-900. DOI:10.1021/es2024498

Statistics Sweden, 2012. Fertilisers in the agriculture sector 2010/11 (Gödselmedel i jordbruket 2010/11), Statistics Sweden, Stockholm.

Stenström, T.A., Hoffner, S., von Brömsen, U., 1980. Reduction of bacteris and virus in wastewater infiltration - a review, Swedish Environmental Protection Agency, Solna, Sweden.

Stephen, A.M., Cummings, J., 1980. The microbial contribution to human faecal mass. Journal of Medical Microbiology, 13(1): 45-56.

Sunnotel, O. et al., 2006. Cryptosporidium. Letters in Applied Microbiology, 43(1): 7-16. DOI:10.1111/j.1472-765X.2006.01936.x

Swaffer, B.A. et al., 2014. Investigating source water Cryptosporidium concentration, species and infectivity rates during rainfall-runoff in a multi-use catchment. Water Research, 67: 310-320. DOI:http://dx.doi.org/10.1016/j.watres.2014.08.055

Swedish Environmental Emission Data, 2006. Input data small point sources for PLC5 report 2007. SMED, Norrköping, Sweden.

Swedish Environmental Protection Agency, 2004. Present knowledge of on-site wastewater treatment systems in Swedish municipalities, a survey (Kunskapsläget om enskilda avlopp i Sveriges kommuner, en enkätstudie). 5415, Swedish Environmental Protection Agency, Stockholm.

Tang, J. et al., 2011. Modelling Cryptosporidium oocysts transport in small ungauged agricultural catchments. Water Research, 45(12): 3665-3680.

DOI:http://dx.doi.org/10.1016/i.watres.2011.04.013

The Council of Water and Wastewater Cooperation in Stockholm County, 2011. Robust and Climate Safe Drinking Water Supply in Stockholm County. WWCSC-Council report nr 10, The Council of Water and Wastewater Cooperation in Stockholm County \& The County Board of Stockholm, Stockholm, Sweden.

WHO, 2011. Guidelines for drinking-water quality, 4th edition. World Health Organisation, Geneva, Switzerland, $564 \mathrm{pp}$.

Winchell, M., Srinivasan, R., Di Luzio, M., Arnold, J., 2013. ArcSWAT (2013) interface for SWAT 2012 User's guide, Blackland Research and Extention Center Texas Agrilife Research \& Grassland, Soil and Water Laboratory USDA Agricultural Research Service, Temple, Texas, USA.

Wyman, J., Heaton, K., Manning, A., Wicks, A., 1978. Variability of colonic function in healthy subjects. Gut, 19(2): 146-150. 
Accepted version - Final version available: http://dx.doi.org/10.1016/j.jhydrol.2016.11.011

0022-1694/@2016 This version is made available under the CC-BY-NC-ND 4.0 license

Xiao, L., Herd, R.P., 1994. Infection patterns of Cryptosporidium and Giardia in calves. Veterinary Parasitology, 55(3): 257-262. DOI:http://dx.doi.org/10.1016/0304-4017(93)00645-F

Yang, J., Li, G., Wang, L., Zhou, J., 2015. An Integrated Model for Simulating Water Resources Management at Regional Scale. Water Resources Management, 29(5): 1607-1622. 
Accepted version - Final version available: http://dx.doi.org/10.1016/j.jhydrol.2016.11.011

0022-1694/@2016 This version is made available under the CC-BY-NC-ND 4.0 license

\section{Appendix A}

Table A.1 Log10 reduction in the Cryptosporidium and E. coli maximum concentration in the different sub-basins for the four mitigation scenarios (M1-M4). The figures are rounded off to two decimal points. M1 - Vegetative filter strip was added to the areas where manure was spread. M2 - Vegetative filter strip was added to the areas where grazing animals were kept. M3 - Underperforming OWTSs were assumed to be replaced or maintained so that all OWTS obtained $99 \%$ removal of both Cryptosporidium and E. coli. M4 - Wastewater treatment plants increased the removal of Cryptosporidium and E. coli by one Log10 unit, from 1.3 and 2.4 to 2.3 and $3.4 \log 10$ units for respectively.

\begin{tabular}{|c|c|c|c|c|c|c|c|c|}
\hline \multirow[b]{2}{*}{$\begin{array}{l}\text { Sub- } \\
\text { basin }\end{array}$} & \multicolumn{2}{|c|}{ M1 } & \multicolumn{2}{|c|}{ M2 } & \multicolumn{2}{|c|}{ M3 } & \multicolumn{2}{|c|}{ M4 } \\
\hline & $\begin{array}{c}\text { Crypto- } \\
\text { sporidium }\end{array}$ & E. coli & $\begin{array}{c}\text { Crypto- } \\
\text { sporidium }\end{array}$ & E. coli & $\begin{array}{c}\text { Crypto- } \\
\text { sporidium }\end{array}$ & E. coli & $\begin{array}{c}\text { Crypto- } \\
\text { sporidium }\end{array}$ & E. coli \\
\hline 1 & 0.00 & 0.00 & 0.00 & 0.00 & 0.00 & 0.00 & 1.00 & 1.00 \\
\hline 2 & 0.26 & 0.28 & 0.00 & 0.00 & 0.00 & 0.00 & 0.00 & 0.00 \\
\hline 3 & 0.00 & 0.00 & 0.00 & 0.00 & 0.00 & 0.00 & 1.00 & 1.00 \\
\hline 4 & 0.00 & 0.00 & 0.00 & 0.00 & 0.00 & 0.00 & 1.00 & 0.82 \\
\hline 5 & 0.00 & 0.00 & 0.00 & 0.00 & 0.00 & 0.00 & 1.00 & 0.57 \\
\hline 6 & 0.32 & 0.38 & 0.00 & 0.00 & 0.00 & 0.00 & 0.00 & 0.00 \\
\hline 7 & 0.30 & 0.37 & 0.00 & 0.00 & 0.00 & 0.00 & 0.00 & 0.00 \\
\hline 8 & 0.00 & 0.00 & 0.00 & 0.00 & 0.00 & 0.00 & 1.00 & 0.54 \\
\hline 9 & 0.41 & 0.46 & 0.00 & 0.00 & 0.01 & 0.00 & 0.00 & 0.00 \\
\hline 10 & 0.29 & 0.35 & 0.00 & 0.00 & 0.00 & 0.00 & 0.00 & 0.00 \\
\hline 11 & 0.27 & 0.33 & 0.00 & 0.00 & 0.00 & 0.00 & 0.00 & 0.00 \\
\hline 12 & 0.00 & 0.00 & 0.00 & 0.00 & 0.00 & 0.00 & 1.00 & 0.80 \\
\hline 13 & 0.23 & 0.28 & 0.00 & 0.00 & 0.00 & 0.00 & 0.00 & 0.00 \\
\hline 14 & 0.34 & 0.39 & 0.00 & 0.00 & 0.00 & 0.00 & 0.00 & 0.00 \\
\hline 15 & 0.34 & 0.38 & 0.00 & 0.00 & 0.00 & 0.00 & 0.00 & 0.00 \\
\hline 16 & 0.00 & 0.00 & 0.00 & 0.00 & 0.00 & 0.00 & 1.00 & 0.60 \\
\hline 17 & 0.31 & 0.38 & 0.00 & 0.00 & 0.00 & 0.00 & 0.00 & 0.00 \\
\hline 18 & 0.28 & 0.33 & 0.00 & 0.00 & 0.00 & 0.00 & 0.00 & 0.00 \\
\hline 19 & 0.31 & 0.38 & 0.00 & 0.00 & 0.01 & 0.00 & 0.00 & 0.00 \\
\hline 20 & 0.30 & 0.35 & 0.00 & 0.00 & 0.00 & 0.00 & 0.00 & 0.00 \\
\hline 21 & 0.00 & 0.30 & 0.00 & 0.00 & 0.00 & 0.00 & 0.28 & 0.00 \\
\hline 22 & 0.28 & 0.34 & 0.00 & 0.00 & 0.00 & 0.00 & 0.00 & 0.00 \\
\hline 23 & 0.00 & 0.00 & 0.00 & 0.00 & 0.00 & 0.00 & 1.00 & 0.51 \\
\hline 24 & 0.00 & 0.31 & 0.00 & 0.00 & 0.00 & 0.00 & 0.27 & 0.00 \\
\hline 25 & 0.00 & 0.30 & 0.00 & 0.00 & 0.00 & 0.00 & 0.33 & 0.00 \\
\hline 26 & 0.00 & 0.30 & 0.00 & 0.00 & 0.00 & 0.00 & 0.32 & 0.00 \\
\hline 27 & 0.00 & 0.26 & 0.00 & 0.00 & 0.00 & 0.00 & 0.57 & 0.00 \\
\hline 28 & 0.00 & 0.27 & 0.00 & 0.00 & 0.00 & 0.00 & 0.50 & 0.00 \\
\hline 29 & 0.41 & 0.42 & 0.00 & 0.00 & 0.00 & 0.00 & 0.00 & 0.00 \\
\hline 30 & 0.00 & 0.00 & 0.00 & 0.00 & 0.00 & 0.00 & 1.00 & 0.28 \\
\hline 31 & 0.00 & 0.00 & 0.00 & 0.00 & 0.00 & 0.00 & 1.00 & 0.84 \\
\hline 32 & 0.36 & 0.42 & 0.00 & 0.00 & 0.00 & 0.00 & 0.00 & 0.00 \\
\hline 33 & 0.00 & 0.00 & 0.00 & 0.00 & 0.00 & 0.00 & 1.00 & 0.31 \\
\hline 34 & 0.37 & 0.41 & 0.00 & 0.00 & 0.00 & 0.00 & 0.00 & 0.00 \\
\hline 35 & 0.00 & 0.00 & 0.00 & 0.00 & 0.00 & 0.00 & 1.00 & 0.31 \\
\hline
\end{tabular}

